\title{
7 Social Enterprise in Ireland
}

State Support Key to the

Predominance of Work-

Integration Social

Enterprise (WISE)

\author{
Patricia O'Hara and \\ Mary O’Shaughnessy
}

\section{Introduction}

Social enterprise (SE) in Ireland takes on many forms across a spectrum from local community-based entities to large businesses trading internationally. The SE sector is regarded as being part of the wider social economy, which includes cooperatives, mutual societies, non-profit associations and foundations. Understanding of the sector-its boundaries, scale and potential-has been influenced by academic and policy approaches. In Irish academic discourse, conceptualisation of social enterprise owes much to both US and European academic traditions. By contrast, more than two decades of Irish public-policy debate has viewed social enterprise as a mechanism of job creation/integration and service provision in disadvantaged communities-a policy perspective significantly influenced by European policy on the sector. These variations in approach have contributed to ambiguity about the nature and extent of the social economy as a sector and social enterprises as distinctive entities, which, in turn, has compromised attempts to estimate the scale and potential of the sector in Ireland.

The National Social Enterprise Policy for Ireland 2019-2022 marked the first significant policy declaration on social enterprise; it states that social enterprises "make a valuable contribution to the economic and social progress of Ireland through the creation of jobs and delivery of a broad range of services" (Government of Ireland 2019: 5). While there is still some ambiguity about the phenomenon's extent and potential, this development has helped to bring greater clarity about the nature of social enterprise in Ireland and reinforced the view of social enterprises as businesses whose core objective is to achieve a social, societal or environmental impact through labour-market integration and the delivery of a range of services, including the provision of training. It is clear that much of the financial support for Irish social enterprises, to date, is provided through labour-market activation schemes and that this

DOI: $10.4324 / 9780429055140-7-9$ 
accounts for the dominance of the work-integration social enterprise (WISE) model in the Irish SE landscape. WISEs exist mainly to improve the employability and employment prospects of people furthest from the labour market; they often combine this objective with an additional goal of providing a range of community-based goods and services.

The objectives of this chapter are to discuss how the social economy and social enterprise are understood in Ireland; to explain how WISEs have evolved as the dominant Irish SE model to date; and to describe some of the current challenges facing WISEs and their prospects for the future. The chapter is structured into three parts. In the first two parts, we discuss the influence of the US (Salamon and Anheier 1997; Dees 1998) and European/EMES (Pestoff 1998; Borzaga and Defourny 2001; Nyssens 2006; Defourny and Nyssens 2010, 2012) academic traditions, and of EU and national policy perspectives, since the early 1990s, on Irish academic and policy discourse, respectively. While academic studies, drawing on a variety of sources, have yet to agree on the boundaries of the social economy or social enterprise, policy approaches have evolved considerably. We argue that the labour-market integration approach to the development of the Irish social economy, adopted by successive Irish governments in recent decades, has shaped the sector and contributed to the emergence of one dominant SE type, namely the WISE. In the third part of the chapter, we present a brief overview of the typical Irish WISE operational model and the challenges these enterprises face in the context of wider developments in the SE landscape.

\subsection{Social Enterprise in Irish Academic Discourse-US and European Influences}

Although Ireland has a long and rich tradition of social-economy-type organisations (including social enterprises), it is only since the early 1990s that the sector has been subjected to significant academic attention and that the concept of social enterprise has become prominent. Early Irish academic discourse tended to reflect US work on the non-profit sector (e.g., Powell and Guerin 1997; Salamon and Anheier 1997; Donoghue 1998; Donoghue et al. 1999; Acheson et al. 2003; Prizeman and Crossan 2011) or be influenced by the European tradition, particularly that of the EMES Network (O'Hara 2001; O'Shaughnessy 2008; Curtis et al. 2011). This is in line with approaches elsewhere, which can be broadly characterised as either US or European, depending on the weight given to individualistic and hierarchical organisational structures, on the one hand, or collectivisation and democratic ownership, on the other (Spear and Bidet 2005; Nicholls 2006; Mendell 2010; Teasdale 2011).

Most studies of the Irish non-profit sector grounded in the US tradition were based on the Johns Hopkins' definition of non-profits (Salamon and Anheier 1997; Donnelly-Cox 1998). One of the earliest investigations 
(Donoghue 1998), using the Johns Hopkins' definition (Salamon and Anheier 1997) to map the sector, pointed to the long history of nonprofits, the absence of a specific policy milieu and the reliance of these organisations on public funds and volunteering. A further mapping exercise (Donoghue et al. 2006) used the International Classification of Non-Profit Organisations. Thus, the term social enterprise did not appear in any academic mapping exercise of the Irish non-profit sector (influenced by the US non-profit approach) until a philanthropicsponsored study of the sector was published in 2011. Prizeman and Crossan's (2011) mapping exercise was influenced by the US emphasis on social innovation and social entrepreneurship (Dees 1998; Dees and Anderson 2006). In this study, the authors considered social enterprises as one type of initiatives among a wider set, ranging from individual social entrepreneurs to social entrepreneurial initiatives. This research provided an insight into the entrepreneurial behaviours of individuals/ enterprises; their role in public service delivery; their networks, relationships and stakeholders; their financial and human resources; and their impacts, values and governance. It also confirmed the highly diverse and multifaceted nature of the Irish social economy and the complex missions, organisational structures, networks and entrepreneurial behaviours that characterised individual Irish social entrepreneurs and social enterprises.

While the term social enterprise was not used in US-influenced academic studies of the Irish non-profit sector until 2011, the concept appeared much earlier-in 2001 already-in studies influenced by the European/EMES tradition. O'Hara (2001) delineated five broad categories of Irish social enterprises according to the conceptual framework of the EMES International Research Network and using the set of nine EMES indicators. ${ }^{1}$ Focusing on objectives, activities and operation, rather than on organisational forms, the categories were (1) workintegration social enterprises, associated with insertion of members of excluded groups into the labour force; (2) credit unions; (3) social enterprises concerned with housing provision; (4) social enterprises providing personal and proximity services; and (5) local-development organisations.

Work-integration social enterprises provide work and labour-market integration primarily for people with disabilities in what was conventionally referred to as "workshops" or "sheltered employment". Structured as cooperatives, credit unions provide financial services and have a very high membership in Ireland. Social enterprises concerned with housing provision, including housing cooperatives and voluntary/philanthropic housing associations, are significant providers of social housing in the country. Similarly, social enterprises that provide personal and proximity care are an important element of the Irish care sector, particularly in the provision of child care and services to older persons. Local development organisations or 
community-based service organisations emerged in the 1990s as part of the state response to the persistence of long-term unemployment and disadvantaged communities and gave rise to a new generation of social enterprises in the context of state support for labour-market integration. These five categories were not seen as mutually exclusive; they were rather to be viewed as being at different points on what Defourny and Nyssens (2012) later referred to as the "galaxy" of social enterprises, with the first four types being more typical of the non-profit/voluntary sector or established social economy.

This EMES-type approach was not applied again to any systematic mapping of the Irish social economy until a study sponsored by the European Commission was undertaken, in 2014, as part of a mapping exercise of SE activity and ecosystems across the EU (this study was subsequently updated, in 2016 and 2019; see European Commission 2014, 2016, 2019). The operational definition of social enterprise used for these exercises was based on that used in the 2011 European Commission's Social Business Initiative (European Commission 2011) and closely mirrored the widely accepted EMES definition. Six types of Irish organisations that might be considered as social enterprises were identified: (1) community-based organisations receiving grant aid to provide temporary employment and job training; (2) charities and voluntary organisations delivering public services on a grant or contract basis; (3) friendly societies; (4) socially entrepreneurial individuals launching socially motivated businesses; (5) entrepreneurial sports, cultural and community organisations; and (6) credit unions and cooperatives. These types closely resembled the categories originally outlined by O'Hara (2001), with the exception of the omission of social enterprises concerned with social housing as a separate category, and inclusion of two additional types in the 2014/2016 mapping studies, that is, socially entrepreneurial individuals and friendly societies. The inclusion of the former reflected the influence of the US social-innovation school of thought, while the latter are a legal form that was often used by non-profits until 2018. ${ }^{2}$ This mapping exercise also referred to the interchangeable use of concepts such as social enterprise and social entrepreneurship in Irish discourse, underlining the general vagueness surrounding these concepts in Ireland.

In summary, Irish academic discourse on the social economy and social enterprise reflects a variety of conceptualisations and definitions that draw upon different academic traditions. The results of this have been an ambiguous understanding of concepts and an unreliable assessment of the true scale and potential of the sector. As noted in the European Commission's report on social enterprises and their ecosystems in Ireland (European Commission 2014, 2016, 2019), there are considerable knowledge gaps about Irish social enterprises, including about their scale, social impact and overall contribution to the national economy and society in general. Numerous small-scale surveys confirm 
SE activity in food and catering, tourism, arts, culture, music, recycling, transport and distribution; social enterprises serve both the businessto-business and public-sector markets, and they also sell directly to individual markets (Hynes 2016). However, there is no real consensus about the size of the sector or its parameters, and indeed, many of the practitioners within the sector have a confused understanding of-and do not identify with-the terms "social economy" and "social enterprise". Social enterprises are not included in official statistics, and estimates vary greatly and can be easily contested.

\subsection{Social Enterprise in Irish Policy Discourse}

By contrast with what is the case in the academic field, conception of the social economy in Irish policy discourse has been more vigorous and less confused, having been strongly influenced, since the early 1990s, by a European policy perspective that promoted the social economy and social enterprise as a community-based strategy to tackle unemployment and social and economic exclusion.

\subsubsection{The First Two Decades: The 1990s and 2000s}

The terms "social economy" and "social enterprise" first emerged in Irish policy discourse in the 1990s and reflected European policy trends of the time (European Commission 1993, 1995a, 1995b). The initial Irish policy debate on the sector was influenced by a study that identified social enterprises as having the potential to provide goods and services to disadvantaged communities in the instance of market and public-service failure, and to facilitate local labour-market integration (National Economic and Social Forum 1995). The National Economic and Social Forum $(\mathrm{NESF})^{3}$ recommended that government action be taken to develop the social economy by creating support structures for socialeconomy enterprises and providing subsidies to those enterprises that would recruit from the unemployed. These recommendations were subsequently supported by advocacy groups for the unemployed, who produced position papers on how the sector could be developed and supported to provide community-based services and tackle unemployment and social exclusion (see PLANET 1997, 2005; WRC Social and Economic Consultants 1999).

The Irish government responded by establishing a Working Group on the Social Economy to undertake a detailed examination of the potential of the sector to provide employment and services in disadvantaged communities. In its 2000 report, the Working Group reiterated the NESF's earlier call for government support and reinforced the association between the social economy, labour-market integration and service delivery to disadvantaged communities. They recommended the 
establishment of a national social-economy programme that would use existing labour-market integration programmes wherever possible to support the sector. This led to the establishment of the Social Economy Programme (SEP) in 2000. The objective of the SEP was to support social enterprises with specific characteristics such as community ownership, a local development focus and a mission to provide work-integration opportunities for the long-term unemployed. These features reflected key elements of the EMES ideal type of social enterprise and the European policy focus on linking development of the social economy to tackling unemployment (Nyssens 2006; Defourny and Nyssens 2012). The SEP was introduced at a time when Ireland was experiencing virtually full employment and attracting significant inward migration to fill the jobs available. Thus, participating social enterprises were required to have a specific focus on funding local services and providing employment opportunities for particularly disadvantaged groups (including those distant from the labour market), or to address market or public-service failure in communities, usually as a consequence of either geographical or social isolation. In this way, the establishment of new social enterprises was linked explicitly to government objectives of labourmarket re-integration, local and community development and the provision of local services.

An evaluation of the SEP found that the programme had limited capacity to support the development of social enterprises and that there was insufficient start-up support and enterprise training; the evaluation also questioned the long-term sustainability of the social enterprises supported under the programme (WRC Social and Economic Consultants 2003). This led to further calls for a mapping of the social economy and the development of a new national policy to strengthen and support the sector (PLANET 2005). ${ }^{4}$ By 2006, responsibility for the SEP had been transferred from the government department concerned with enterprise and employment to that with responsibility for community and rural affairs, and the SEP was renamed as the Community Services Programme (CSP). This change of name and the transfer of administrative responsibility for the programme strengthened the association of social enterprises with locally based community development rather than with enterprise and entrepreneurship. CSP social enterprises are not expected to become financially sustainable, and many remain dependent on state funding. However, they are encouraged to secure income from trading and other sources to deliver properly resourced and viable services. In a 2009 study, Curtis et al. (2011) found that, for a third of social enterprises in the programme, trading accounted for less than $20 \%$ of total income. Fewer than a quarter $(22 \%)$ generated more than half their income from trade. Four out of ten enterprises surveyed on their views on the requirement to generate a traded income responded that they would prefer a funding stream that did not have this 
requirement. Thus, it is clear that a very significant share of organisations that participate in the CSP are not enterprise-driven and that they exhibit an extensive reliance on, and operate primarily as conduits for, state funding programmes (WRC Social and Economic Consultants 2003; Clann Credo 2011; Curtis et al. 2011).

In short, state labour-market activation schemes became the key stimulus and support for the development of Irish social enterprises from the 1990s onward. Consequently, the social enterprises that have emerged from this type of state support typically support labour-market integration and are engaged in community service provision, and they can generally be categorised as WISEs.

\subsubsection{Emerging from Recession: A New Definition}

In 2012, the Irish government published an Action Plan for Jobs as part of its response to the national recession, which was characterised by a crisis in public finances and high unemployment. This Action Plan contained a series of concrete actions to maximise employment creation and included a working definition of social enterprises as business models set up to tackle social, economic or environmental issues and engaged in trading or commercial activities to produce social and community gain (Government of Ireland 2012: 67). A subsequent review of the job-creation potential of social enterprise, carried out by Forfás, ${ }^{5}$ defined social enterprises as not-for-profit organisations, driven by social objectives, separate from government, where at least part of the income generated is from trading activity and the surplus is reinvested in social objectives. Social enterprises were identified as operating on an economic continuum, with varying degrees of commercial focus and engagement with the public and private sectors. At one end of this continuum are those enterprises that deliver core social programmes, such as services for people with disabilities or older people, and that are funded primarily by the state. These are driven by the need to generate enough income to maintain their viability and sustainability so that they can respond to social needs. At the other end are those social enterprises that are seen to interface more closely with the commercial sector and that present themselves as businesses that aim at profit maximisation in order to fund their social objectives. Social enterprises were considered by Forfás to be rooted in local and community development and to play an important role in providing jobs to those most distant from the labour market, both spatially and socially (Forfás 2013).

Four types of social enterprise were distinguished by Forfás, largely on the basis of their objectives and activities, rather than their organisational forms: 
- social enterprises that create employment opportunities for marginalised groups, such as people with disabilities or ex-offenders;

- local enterprises that are involved in local and community development and respond to a gap in infrastructure or services, such as community enterprises or community shops;

- organisations that deliver public services, such as child-care or eldercare services;

- organisations that trade in services or products that deliver a social dividend and have a high income-generation capacity, such as environmental services enterprises.

These four types are not mutually exclusive, and it is acknowledged that, in practice, there is overlap. However, the first type-social enterprises creating employment opportunities for marginalised groups—can be seen to correspond to the basic definition of a WISE. Social enterprises involved in local and community development and the delivery of child-care and elder-care services typically utilise labour-market integration programmes, so that they too can be characterised as WISEs. Six case studies were chosen to reflect the diversity of Irish social enterprises (Forfás 2013: 15). Five of these were WISEs, with a clear objective of job creation/training and/or labour-market integration of the long-term unemployed and persons with intellectual/physical disabilities; this choice of examples confirms the dominance of the WISE model in the Irish context to date. This prominence is in line with developments across Europe, where assisting the integration, into the workplace, of unemployed individuals and/or others at risk of social and economic exclusion has become a key objective of European public policy (Nyssens et al. 2012).

\subsubsection{A New National Social Enterprise Policy for}

Ireland (2019-2022)

Following the publication of the Forfás review, a number of developments paved the way for the publication, in 2019, of Ireland's first National Social Enterprise Policy. The lack of direct support to social enterprises was being continually highlighted in various reports (GECES 2016; Hynes 2016; OECD/European Union 2017). In 2017, responsibility for social enterprise was transferred from the government Department of Business, Enterprise and Innovation to the newly established Department of Rural and Community Development (DRCD); in the same year, the Department of Justice and Equality also supported a Social Enterprise Strategy. ${ }^{6}$ A research partnership between the DRCD and the Social Finance Foundation (SFF) led to the publication of a report in 2018 which provided the evidence base for the new policy. Data sources for this study included the Irish Social Mapping Exercise referred to above, a series of thematic national stakeholder consultations, SE site visits and an online survey of SE stakeholders. 
The findings confirmed the extensive range of activities undertaken by Irish social enterprises, including tackling social and environmental issues, fulfilling government contracts to provide social services, generating employment and providing services to the most marginalised groups in society. Six categories of social enterprises were identified: communitybased social enterprises; social-entrepreneurs-initiated social enterprises; work-integration social enterprises; service providers to the state; enterprise-development social enterprises (i.e., social enterprises that support the creation of other enterprises, for example, through the provision of office space and other facilities); and environmental social enterprises (Department of Rural and Community Development and Social Finance Foundation 2018). ${ }^{8}$ The research also pointed to the predominance of social "micro-enterprises", with low levels of earned income, relatively few employees and a high reliance on volunteers. The provision of training and employment opportunities, establishment and maintenance of community facilities/buildings and delivery of community services were found to be the most significant areas of activity among social enterprises, confirming the continued dominance of the WISE model.

The National Social Enterprise Policy for Ireland 2019-2022, based on the research and consultations outlined above, sets out the following broad definition of social enterprise:

- A social enterprise is an enterprise whose objective is to achieve a social, societal or environmental impact, rather than maximising profit for its owners or shareholders.

- It pursues its objectives by trading on an ongoing basis through the provision of goods and/or services, and by reinvesting surpluses into achieving social objectives.

- It is governed in a fully accountable and transparent manner and is independent of the public sector. If dissolved, it should transfer its assets to another organisation with a similar mission.

While the lack of comprehensive data on the full extent and impact of social enterprise SE in Ireland is acknowledged, social enterprises are seen as delivering a wide range of goods and services and as contributing to the achievement of government policy goals in areas such as labour-market activation, health care, climate action, social cohesion and rural development. Social enterprises are regarded as taking on a variety of different forms, including WISEs. This current Irish national definition of social enterprise parallels the three main dimensions of the EMES approach to social enterprise ${ }^{9}$ and the EU operational definition, ${ }^{10}$ as illustrated in table 7.1. 
Ireland 121

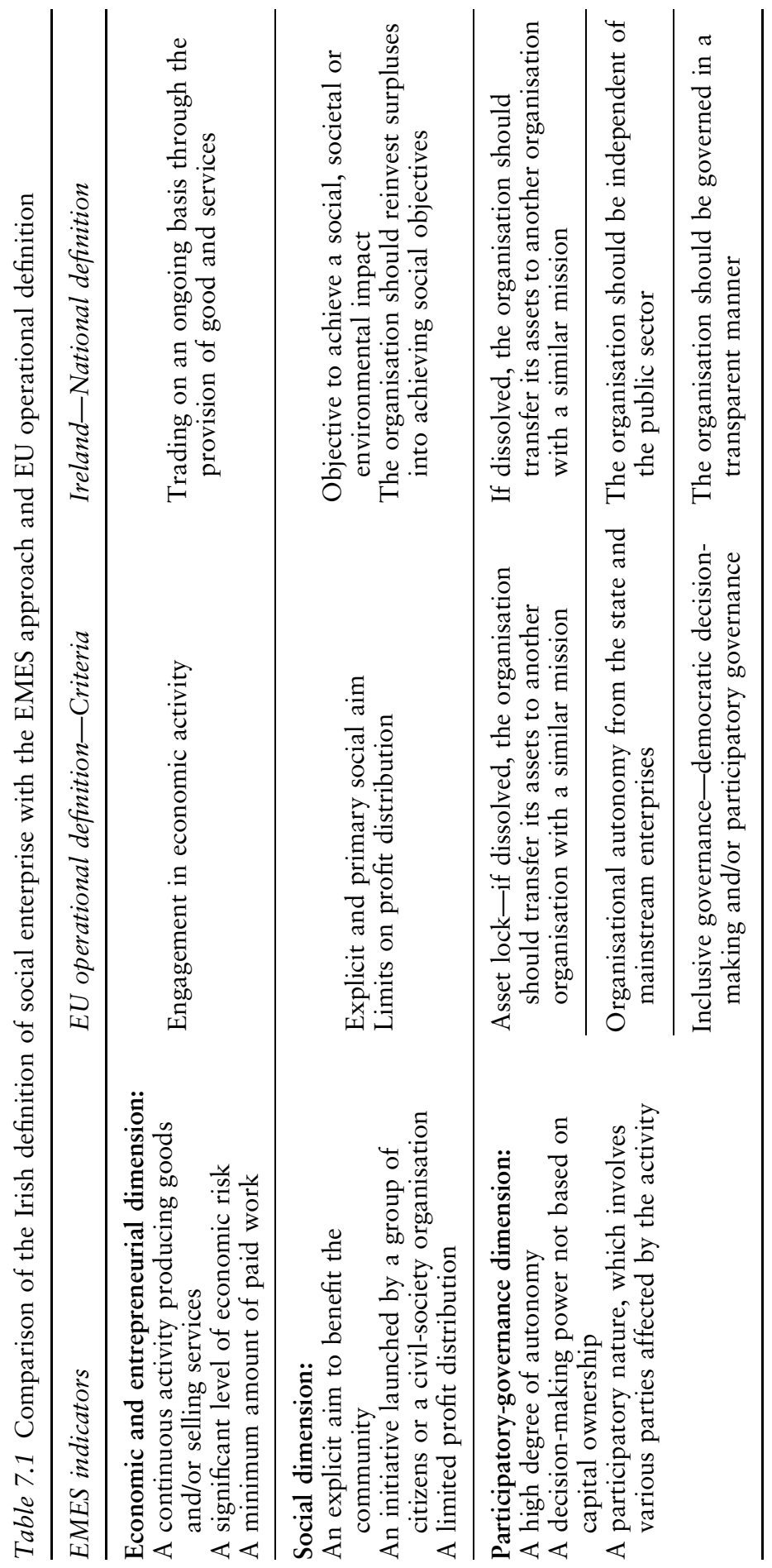




\subsection{WISEs: A Typical Operational Model in Ireland}

In this section, we provide a brief overview of the typical operational model of Irish WISEs-their form and structure, objectives, the services they provide and some of the challenges they face.

\subsubsection{Legal Form and Governance Structure}

There is no specific legal form for Irish social enterprises in general, nor for WISEs in particular. Four different legal structures are available to social enterprises under Irish law: company limited by guarantee (CLG); company limited by shares; designated activity company; and unincorporated association. CLG is the most popular legal form for Irish notfor-profits, including WISEs, because no shares are issued and there are provisions in the articles of association that prohibit the payment of dividends to the members of the enterprise. Because a CLG does not have shares, it cannot raise funds by way of equity investment.

Irish WISEs that carry out charitable activities may also apply for charitable status and thus benefit from certain tax exemptions, subject to approval from the Irish Revenue authorities. However, charitable status also requires additional regulatory reporting and statutory filing obligations, and certain clauses (including the prohibition of remuneration to the board of directors) must be included in the WISE's governance rules.

National advocacy groups for the sector have called for a specific legal identity for social enterprise in order to distinguish social enterprises from other organisations, provide greater visibility for the sector and facilitate greater accuracy in the measurement of the true scale of its social and economic impact (Moroney and O'Shaughnessy 2017: 5).

\subsubsection{Social Objectives and Sustainability}

The primary social objective of a WISE is to hire people who are most distant from the labour market, to improve their employability and increase their employment rates while providing goods and services. WISEs deal with workers who are vulnerable due to factors such as disability, intergenerational unemployment, long-term unemployment, a history of substance abuse, low educational attainment level or criminal conviction. Apart from employment, WISEs provide targeted support, such as mentoring and training, to improve employees' self-confidence and work readiness.

Irish WISEs mobilise a diversity of resources to self-sustain. They typically generate a traded income by providing a range of goods and services and may benefit from corporate social responsibility (CSR) initiatives and philanthropy. They utilise state labour-market activation schemes, such as CSP, to support wages or cover part of the cost of provision of services to 
users; they may access the Dormant Accounts Fund (DAF) $)^{11}$ to provide training and mentoring.

\subsubsection{Goods and Services Provided}

Irish WISEs tend to be locally based and provide a diversity of goods and services which benefit their communities and create local training and employment opportunities. Typical goods and services include child/ elder care, environmental/recycling services, sporting, cultural and leisure services, mattress recycling, maintenance of community buildings, tourism, food production/catering services, crafts, training and educational services. A growing sector of Irish WISEs are specifically focused on people with criminal convictions, who face a wide range of barriers in securing and maintaining employment. These types of WISE benefit from targeted state support through the Department of Justice and Equality Kick Start Social Enterprise Fund, launched in 2018, and they typically deliver bicycle, wheelchair and lawnmower repair services, wooden furniture upcycling, catering and contract packing.

\subsubsection{Challenges for WISEs}

In this section, some of the key challenges faced by Irish WISEs are briefly discussed.

\section{Limitation of the Labour-Market Pool}

As noted throughout this chapter, state support for WISEs typically takes the form of labour-market activation programmes. While it is widely acknowledged that this type of support can help reduce the costs of doing business for the social enterprise, the strict requirements of such schemes are perceived as a challenge for WISEs that are ambitious to be more commercially driven, competitive and keen to widen their offer of goods and services. Since Irish WISEs work with vulnerable individuals, they bear the associated costs of providing significant support to meet their needs and, in some instances, of adjusting the workplaces accordingly. These costs can mitigate against the competitiveness of the WISE and/or its ability to be commercial. As we have noted above, WISEs typically emerged in the context of a political response to high national unemployment levels, and as a way of providing essential goods and services to vulnerable communities. However, in more buoyant economic times, with high employment rates, ${ }^{12}$ WISEs are increasingly challenged by having to provide extensive support to employees, often sourced from a limited labour-market pool, and distant from the labour market for extensive time periods. 


\section{O’Hara \& O’Shaughnessy}

\section{Lack of Business and Leadership Skills}

Irish social enterprises, including WISEs, are largely area based and managed by community members. They contribute to local community, social and economic development, increase social cohesion and retain local social capital (O'Shaughnessy and O'Hara 2013; Hynes 2016). However, localisation can also be a challenge for WISEs if they do not have access to a diverse and skilled voluntary board of directors with a knowledge of local, regional, national and international market opportunities, strategic vision and a strong (social) entrepreneurial focus. The enterprise and management skills required throughout the business life cycle of Irish WISEs include administrative support in scheme application and compliance, long-term business planning and the development of market-sector networks (Department of Rural and Community Development and Social Finance Foundation 2018; Olmedo et al. 2019). In an online consultation of 376 Irish social enterprises carried out in $2017,71 \%$ of the respondents said that current business supports did not meet the specific needs of the sector. Furthermore, 329 respondents expressed a need for additional training in business and leadership skills, including performance and impact measurement, marketing, sales, HR and recruitment, tendering and procurement (Department of Rural and Community Development and Social Finance Foundation 2018). The challenge of upskilling in business tendering and procurement is particularly pressing, given the Irish government's 2018 commitment to incorporating social considerations into public procurement as part of their efforts to encourage more social enterprises to participate in competitive tendering for public contracts. ${ }^{13}$

\section{Unstable Resource Environments}

Social enterprises, including WISEs, have demonstrated a capacity to mobilise and combine a diverse range of resources to achieve their objectives (di Domenico et al. 2010; Cooney et al. 2016; O'Shaughnessy and O'Hara 2016). Irish WISEs are, to a greater or lesser extent, reliant on philanthropy, initiatives associated with corporate social responsibility and high levels of volunteerism. Consequently, they operate in an unstable resource environment, as well as being subject to the challenge of short-term public-sector contracts, rule changes to government programmes, changes in volunteering trends, and the increasingly demanding regulatory and reporting requirements imposed on the charity and not-for-profit sector.

As just mentioned, volunteerism is a critical resource for Irish social enterprises, including WISEs. In a 2018 survey of community-based social enterprises, it was estimated that, on average, each social enterprise had 16 volunteer workers and 7 voluntary trustees (Department of Rural and 
Community Development and Social Finance Foundation 2018). However, national trends in volunteering are changing and this has implications for the long-term survival of Irish WISEs. An estimated 29\% of Irish adults volunteer (CSO 2015), but volunteers now tend to seek more flexible, shortterm and one-off volunteering opportunities (Volunteer Ireland 2018). ${ }^{14}$ Furthermore, volunteers in the not-for-profit and charity sectors (including WISEs) are increasingly critical of the time they are required to spend on what they perceive to be excessive administration and form filling to meet regulatory requirements.

\section{Conclusions}

In this chapter, we have attempted to provide an insight into how the social economy and social enterprise are understood in Ireland and to explain why WISEs have evolved as the dominant Irish SE model to date. We have argued that, while there is diversity in the academic approaches to understanding and defining these concepts, there is less ambiguity in public-policy discourse. Successive Irish governments' strategies to date, of developing the social economy in general, and social enterprise more specifically, have evolved via labour-market integration programmes. From the early 1990s, the state has also been informed by a European policy perspective that promotes the social economy and social enterprises as a civil-society-based solution to a range of localised social and economic problems, most notably unemployment and service provision to disadvantaged communities. Therefore, Irish state support for the sector has mainly taken the form of active labour-market schemes, and WISE has evolved as the dominant SE type.

Historically, Irish WISEs emerged to improve the employability/social integration of people most distant from the labour market and to provide a range of community-based goods and services, most often in disadvantaged urban and rural locations. These WISEs are the by-product of government support for social enterprise through active labour-market schemes, in the absence of any clear national policy or strategy on social enterprise. However, publication of Ireland's first National Social Enterprise Policy 2019-2022 represents the culmination of a notable and growing national political, academic and public interest in social enterprise, which has been particularly noticeable since the recession of the late 2000s. The new policy, within months of publication, has stimulated several initiatives, including public information events; the first National Social Enterprise Conference; the emergence of a new national social-economy research network; and the incorporation of SE support and development strategies in local authorities' economic and community plans. ${ }^{15}$

Aside from policy support for social enterprise, there has also been a notable growth, in recent years, in the availability of cash grants, philanthropic investment, and mentoring/business advisory supports for social 
enterprises and more specifically social entrepreneurs. National organisations such as Social Entrepreneurs Ireland and the Social Innovation Fund Ireland (SIFI) focus on supporting high-potential social entrepreneurs to scale up their impact and, in the case of SIFI, social innovations that deal with a range of contemporary issues, such as managing food waste and tackling food poverty/insecurity, improving peoples' mental health and well-being, and addressing sustainability issues that respond to the challenges of global warming and climate change. These new players in the national SE ecosystem, by supporting socially entrepreneurial individuals launching socially motivated businesses, can be seen to represent the US tradition of social enterprise, that is typically individualistic and philanthropic in nature, and focused on traded income and social innovation. These developments are already giving rise to greater diversity of SE forms in Ireland.

For the foreseeable future, however, it is likely that the Irish state will continue to resource WISE as a way of supporting disadvantaged people to prepare for, and participate in, the labour market and as a means of providing a range of community goods and services in disadvantaged urban and rural locations. WISEs are perceived as valuable entities, with the capacity to utilise and replenish social capital and to harness volunteerism in communities. For these reasons, they are likely to continue to dominate in the broader spectrum of social enterprise. However, WISEs are also constrained by their dependency on limited employment grants to deliver local community goods and services. They are hampered by an unstable resource environment; high employee support costs; weak internal leadership and business skills and capacity to navigate regulatory requirements; and limited ability to provide evidence of social and economic impact. Unless these challenges are addressed, and WISEs appropriately supported, most initiatives are unlikely to realise their potential to contribute to the Irish state's ambitious plan for social enterprise as a vehicle for the identification and implementation of innovative ways to address societal issues and help create a sustainable and inclusive future for all citizens.

\section{Notes}

1 EMES is an international research network, established in 1996, with a focus on social enterprises. EMES outlines nine indicators of social enterprise, namely a continuous activity producing good and/or selling services; a significant level of economic risk; a minimum amount of paid work; an explicit aim to benefit the community; an initiative launched by a group of citizens or civil-society organisations; a limited profit distribution; a high degree of autonomy; a decision-making power not based on capital ownership; and a participatory nature which involves various parties affected by the activity.

2 Friendly societies are registered under the Friendly Societies Acts 1896-2018. They were established for various purposes, mostly to provide small lifeassurance benefits, sick benefits and death benefits to members, to provide benefits to non-members, or to promote particular activities or interests. 
3 The NESF was established by the Irish Government in 1993 to develop economic and social-policy initiatives.

4 PLANET is a partnership network representative of area-based partnership organisations established to tackle unemployment in Ireland.

5 Forfás was, until 2014, the national policy advisory board for enterprise, trade, science, technology and innovation in Ireland. When it was dissolved, most of its functions were incorporated into the government department responsible for Business, Enterprise and Innovation.

6 The Irish Probation Services, in cooperation with the Irish Prison Service supported by the Department of Justice and Equality, launched a Social Enterprise Strategy in 2017. The strategy is designed to support workintegration social enterprises to help ex-offenders reintegrate into the labour force.

7 The Social Finance Foundation (SFF) was established in 2007 by the Irish Government to address the needs of community organisations and social enterprises for loan funding.

8 Some social enterprises fall under more than one category.

9 Defourny and Nyssens (2010) define a set of nine indicators to identify organisations likely to be termed social enterprises.

10 This EU operational definition is an operationalisation of the concept of social enterprise as articulated in the EC's Social Business Initiative (SBI) communication adopted on 23 May 2012. This definition incorporates the three dimensions of social enterprise-namely the entrepreneurial, social and governance-related dimensions.

11 The Dormant Accounts Fund (DAF) was established in 2012 to distribute unclaimed funds from accounts in credit institutions in Ireland to support a range of social and economic development initiatives.

12 At the time of writing, Ireland had a national employment rate of just under $95 \%$.

13 This commitment was made on foot of the 2014 EU Procurement Directive and is contained in an information note on public procurement (Office of Government Procurement 2018).

14 In contrast, corporate volunteering initiatives are on the increase, as the corporate world seeks out new CSR opportunities.

15 A number of local authorities have incorporated a goal to support the social-economy sector in their Local Economic Community Plans.

\section{References}

Acheson, E., Harvey, B., Kearney, J. \& Williamson, W. (2003) Two Paths, One Purpose: Voluntary Action in Ireland, North and South, A Report to the Royal Irish Academy Third Sector Research Programme, Coleraine: Centre for Voluntary Action Studies, University of Ulster.

Borzaga, C. \& Defourny, J. (eds) (2001) The Emergence of Social Enterprise, London and New York: Routledge.

Clann Credo (2011) The Economic and Social Contribution of Clann Credo the Social Investment Fund, Dublin: Clann Credo.

Cooney, K., Nyssens, M., O’Shaughnessy, M. \& Defourny, J. (2016) “Public policies and work integration social enterprises: The challenges of institutionalism in a neoliberal era", Nonprofit Policy Forum, Vol. 7, No. 4, pp. 415-433. 
CSO (2015) Statistical Release-QNHS Volunteering and Wellbeing Q3, 2013, CSO: Ireland.

Curtis, A., O'Shaughnessy, M. \& Ward, M. (2011) “An examination of the tensions and challenges associated with operating as a social enterprise-The case of Irish social enterprises", 3rd EMES International Research Conference on Social Enterprise, "Social Innovation through Social Entrepreneurship in Civil Society”, 4th-7th July, 2011, Roskilde, Denmark.

Dees, J. G. (1998) The Meaning of Social Entrepreneurship, Kansas City and Palo Alto: Kauffman Foundation and Stanford University.

Dees, J. G. \& Anderson, B. B. (2006) "Framing a theory of social entrepreneurship: Building on two schools of practice and thought", Research on Social Entrepreneurship, ARNOVA Occasional Paper Series, Vol. 1, No. 3, pp. 39-66.

Defourny, J. \& Nyssens, M. (2010) “Conceptions of social enterprise and social entrepreneurship in Europe and the United States: Convergences and divergences", Journal of Social Entrepreneurship, Vol. 1, No. 1, pp. 32-53.

Defourny, J. \& Nyssens, M. (2012) “The EMES Approach of Social Enterprise in a Comparative Perspective”, EMES Working Papers, No. 12/03, Liege: EMES International Research Network.

Department of Rural and Community Development and Social Finance Foundation (2018) Social Enterprise in Ireland. Research Report to Support the Development of a National Social Enterprise Policy, Dublin: Government of Ireland.

Di Domenico, M., Haugh, H. \& Tracey, P. (2010) "Social bricolage: Theorizing social value creation in social enterprises", Entrepreneurship Theory and Practice, Vol. 34, No. 4, pp. 681-703.

Donnelly-Cox, G. (1998) "A white paper for the Irish voluntary sector Linkages between policy and third sector organizations", Paper presented to the CVO 20th Anniversary Conference, London School of Economics, September 17-18.

Donoghue, F. (1998) "Defining the non-profit sector: Ireland", in Salamon, L. M. \& Anheier, H. K. (eds) Working Papers of the Johns Hopkins University Comparative Non-profit Sector Project, No. 28, Baltimore: The Johns Hopkins Institute for Policy Studies.

Donoghue, F., Anheier, H. K. \& Salamon, L. M. (1999) Uncovering the NonProfit Sector in Ireland-Its Economic Value and Significance, Dublin: National College of Ireland and Baltimore: Johns Hopkins University.

Donoghue, F., Prizeman, G., O’ Regan, A. \& Noel, V. (2006) The Hidden Landscape-First Forays into Mapping Non-Profit Organisations in Ireland, Dublin: Trinity College Dublin.

European Commission (1993) White Paper on Growth, Competitiveness and Employment, European Commission, Brussels.

European Commission (1995a) Action to Turn Growth into Jobs, European Commission, Brussels.

European Commission (1995b) Local Development and Employment Initiatives, European Commission, Brussels.

European Commission (2011) The Social Business Initiative of the European Commission, European Commission Publication, Luxembourg: Publications Office, European Union. 
European Commission (2014, 2016, 2019) Mapping Study on Social Enterprise Ecosystems-Country Report on Ireland, Luxembourg: Publications Office, European Union.

Forfás (2013) Social Enterprise in Ireland, Sectoral Opportunities and Policy Issues, Dublin: Forfás, Dublin, Ireland.

GECES (2016) Social Enterprises and the Social Economy Going Forward, Brussels: Commission Expert Group on Social Entrepreneurship, European Union.

Government of Ireland (2012) Action Plan for Jobs 2012, Dublin: Government Publications.

Government of Ireland (2019) National Social Enterprise Policy for Ireland 2019-2022, Dublin: Government Publications.

Hynes, B. (2016) Creating an Enabling, Supportive Environment for the Social Enterprise Sector in Ireland, Report/submission to the Irish Local Development Network, Ireland.

Mendell, M. (2010) "Reflections on the evolving landscape of social enterprise in North America”, Policy \& Society, Vol. 29, No. 3, pp. 243-256.

Moroney, A. \& O'Shaughnessy, M. (2017) Developing the Social Enterprise Sector in Ireland: A Comparative Perspective, Report prepared for the Social Finance Foundation, Dublin.

National Economic and Social Forum (1995) Jobs Potential of the Services Sector, Report No. 7, Dublin: Government Publications.

Nicholls, A. (ed.) (2006) Social Entrepreneurship. New Models of Sustainable Social Change, New York: Oxford University Press.

Nyssens, M. (ed.) (2006) Social Enterprise-At the Crossroads of Market, Public Policies and Civil Society, London and New York: Routledge.

Nyssens, M., Defourny, J., Gardin, L. \& Laville, J.-L. (2012) “Work Integration Social Enterprises and Public Policy-An Analysis of the European Situation", EMES Working Paper, Liege: EMES International Research Network.

OECD/European Union (2017) Boosting Social Enterprise Development Good Practice Compendium, Paris: OECD Publishing.

Office of Government Procurement (2018) Information Note-Incorporating Social Considerations into Public Procurement, Government of Ireland: Dublin.

O’Hara, P. (2001) “Social enterprises and local development”, in Borzaga, C. \& Defourny, J. (eds) (2001) The Emergence of Social Enterprise, London: Routledge.

Olmedo, L., van Twuijver, M. \& O’Shaughnessy, M. (2019) Community-Based Social Enterprises. Fostering Inclusive Development in Peripheral European Rural Areas, SSE Knowledge Hub, UN Inter-Agency Task Force on Social and Solidarity Economy, United Nations Research Institute for Social Development, Geneva.

O'Shaughnessy, M. (2008) "Statutory support and the implications for the employee profile of rural based Irish Work Integration Social Enterprises (WISEs)", Social Enterprise Journal, Vol 4, No. 2, pp. 126-135.

O'Shaughnessy, M. \& O'Hara, P. (2013) Social Enterprise in Rural Communities, National Rural Network, Ireland

O'Shaughnessy, M. \& O'Hara, P. (2016) “Rural social enterprises-Patterns of emergence and development", International Review of Sociology, Vol 26, No. 2, pp. 223-233. 
Pestoff, V. (1998) Beyond the Market and State. Civil Democracy and Social Enterprises in a Welfare Society, Aldershot: Ashgate.

PLANET (1997) Building the Social Economy: New Areas of Work, Enterprise and Development, Dublin: Pobal.

PLANET (2005) Third Sector Policy Group-Development of Model for Social Economy in Ireland, Dublin: PLANET.

Powell, F. \& Guerin, D. (1997) Civil Society and Social Policy: Voluntarism in Ireland, Dublin: A \& A Farmer.

Prizeman, G. \& Crossan, D. (2011) Mapping Social Entrepreneurship in Ireland, Dublin: Centre for Nonprofit Management, Trinity College.

Salamon, L. M. \& Anheier, H. K. (1997) Defining the Nonprofit Sector, A CrossNational Analysis, Manchester: Manchester University Press.

Spear, R. \& Bidet, E. (2005) "Social enterprises for work integration in 12 European countries: A descriptive analysis", Annals of Public and Cooperative Economics, Vol. 76, No. 2, pp. 195-231.

Teasdale, S. (2011) "What's in a name? Making sense of social enterprise discourses", Public Policy and Administration, Vol. 27, No. 2, pp. 99-119.

Volunteer Ireland (2018) Strategic Plan 2018-2022, Dublin: Ireland.

WRC Social and Economic Consultants (1999) Social Enterprises and the Social Economy, Dublin: WRC Social and Economic Consultants.

WRC Social and Economic Consultants (2003) Evaluation of the Social Economy Programme, Dublin: WRC Social and Economic Consultants. 